\title{
Michel Tournier's Friday, or The Other Island: Rewriting Defoe's Robinson Crusoe with Lacanian Signifiers
}

\author{
Waad Al-Zoubi \\ Department of English Language and Literature, \\ Faculty of Foreign Languages \\ The University of Jordan, Amman, Jordan \\ Mohammad Shaheen \\ Department of English Language and Literature, \\ Faculty of Foreign Languages \\ The University of Jordan, Amman, Jordan
}

\begin{abstract}
The paper aims to demonstrate that Tournier's Friday or the Other Island rewrites Defoe's Robinson Crusoe within the context of the postmodern Lacanian psychoanalysis. The paper illustrates how literature shifts colors to match the surrounding environment. Defoe's expresses the mode of thought of the Enlightenment that operates as a prelude to Western ethnocentricity, and Colonialism. It narrates the story of the unified conscious individual who has a solid faith in the efficiency of reason to understand objective reality. Such a perspective believes that language transparently represents an actual state of the world. Hence, Defoe's adapts Realism as the mode of representation. Tournier modernizes the classical text to fit into the postmodern cultural context, which doubts the certainty of knowledge, introduces the notion of the split subject, and believes that language mediates reality. Tournier tells of the anecdote of the Lacanian split subject whose experience alternate among the registers of the Symbolic, the Imaginary, and the Real. Therefore, anti-realism is Tournier's style of representation. It adapts figurative language as a variety of the signifier to demonstrate that language is an independent entity that constructs subjectivity, reality, and the text. To advocate humanism, and tolerance Tournier utilizes Lacanian insights of the split subject, the uncertainty of knowledge, and meaning.

Keywords: anti-realism, Lacan, Robinson Crusoe, signifier, Tournier

Cite as: Al-Zoubi , W., \& Shaheen, M. (2020). Michel Tournier's Friday, or The Other Island: Rewriting Defoe's Robinson Crusoe with Lacanian Signifiers. Arab World English Journal for Translation \& Literary Studies 4 (2) 91-104.

DOI: http://dx.doi.org/10.24093/awejtls/vol4no2.7
\end{abstract}

Arab World English Journal for Translation \& Literary Studies

ISSN: 2550-1542 |www.awej-tls.org 
AWEJ for Translation \& Literary Studies Volume, 4 Number 2 May 2020

Michel Tournier's Friday, or The Other Island

Al-Zoubi \& Shaheen

\section{Introduction}

Lacan transliterates Freudian's psychoanalysis into Saussurean linguistics. The cross-fertilization breeds the Lacanian subject who is bewildered by the manipulative dynamism of language. For Lacan, language disfigures the fragile subject by imbricating the amorphous being into a structure that exists before and outside the subject's experience. As such, language never expresses the subject's experience. The initiation into language splits the subject into two co-existing selves: an outer cultural one that looks suspiciously at an inner natural counterpart. The former is the conscious being that adheres to the social Law as imposed by language- the consensus system of signification. The latter is the unconscious being that abides to the bodily experience, which seeks to escape the censorship. Lacan (2006) reiterates Freud's claim that the unconscious is "the core of our being" (p. 437), and adds that the content of the unconscious is structured like a language. In the context of the unconscious, the signifier floats freely and infinitely into a chain of signifiers, resisting any obligation to rest upon a single signified. The reality of the unconscious is encrypted in figurative language that makes its content seems like nonsense to the conscious self. The result is the split subject whose outer conscious self is alienated from the inner unconscious twin. The nature of the language of the unconscious becomes evident in dreams wherein images become signifiers; they indeed refer to something significant, but they remain in the shadow because they do not arise meaning. To signify the inner world, the unconscious resorts to the dynamism of substitution and condensation that Lacan transliterates into the linguistic operations of metonymy and metaphor, respectively.

The discourse of language is that of the Other. The need for the mother's recognition, the Other, gives birth to the desire for the integration with the cultural on the expense of the natural. The desire is the trace of helplessness underlying the infant's dependence on the mother who fulfills the primarily bodily needs. When the Other answers to the cry, a language, the infant restores the natural equilibrium, it mistakenly correlates the touches of the Other with pleasure, love, and fulfillment. The Other answers only to the primary bodily need but does not satisfy the surplus psychological desire whose nature is non-substantial. In the realm of Other, the desire copies the linguistic operations of metonymy by substituting one desire for other endlessly. Therefore, the unconscious desire is "indestructible" in the field of the Other (Lacan, 2006, p.432). Not in the Symbolic Order instead in the Imaginary, in the field of the unconscious, that desire meets its "limits" (Lacan, 1998, p. 31). Lacan's epistemology about the nature of the desire has christened the new irrational desiring subject in place of the traditional rational free willing individuals.

Oedipus complex is the result of the metonymic nature of the desire. Due to the dictates of the Law of the Father, the raw desire for being one with the mother is compromised for another. In Lacan's words (1998), "The father, the Name- of- the- father sustains the structure of desire with the structure of law" (p. 34). The Other constitutes the mainspring of desire designating an $I$ that lacks an objet petit $a$ in Lacan's jargon. To find the objet $a$ announces the content un-desiring subject.

The sexual desire hides the ultimate sense of lack that lurks deep in the subject. I need to procreate because I am simply a transitory phenomenon whose function is the survival of the

Arab World English Journal for Translation \& Literary Studies 
species. Sex signifies an awareness of death and is a medium to defeat mortality. Immortality is human's objet petit $a$; as such, the subject is doomed to experience the restlessness of desiring. Lacan (1998) says that:

[I]mmortal life... it is precisely what is subtracted from the living being by virtue of the fact that it is subject to the cycle of sexed reproduction. And it is of this that all the forms of objet petit $a$ that can be enumerated are representative" (p. 198).

Like desire, object petit a operates metonymically; I desire an object hoping to fill the gap within, thereby achieving the ultimate content subject. Since the real objet $a$ is immortality, only death ensures such serenity. The subject unconsciously desires to experience the ultimate pleasure of being, which in the conscious realm is compromised for the sexual pleasure or jouissance in Lacan's terminology. In the sexual sphere, objet a disguises within the figure of the beloved Other, the resultant jouissance is sexual concerning the fulfillment of the need of an organ. The subject seeks to experience the asexual jouissance of being "that need no organ" (Lacan, 1998, p. 198). Since the latter is unobtainable in the Symbolic realm, the Real asexual jouissance belongs to the female experience that has escaped the dominion of language.

The analysis mentioned above demonstrates the language of the inner self. In the social world, the conscious subject faces an omnipotence-signifier (the Law) whose function is to govern the stability of the established order. Lacan demonstrates the subject's social enslavement in a seminar that investigates Poe's "The Purloined Letter." The mysterious letter (the Law) is a quasitranscendental signifier that objectifies the subjects. The letter, whose content and sender is unknown, operates as a master-signifier that drags the subjects (the queen, the minister, and the detective) into a status of inconvenient intersubjectivity that imposes their roles and powers. The letter imposes a "fictional ordering" on the subjects (Lacan, 2006, p. 11). The enigmatic letter "is ultimately a fake, an empty signifier without signified- ... -nobody really knows what it means, but each of them somehow presupposes that the other knows it, that it has to mean 'the real thing'" (Zizek, 2005, p. 368). In other words, the social subject becomes an object whose roles have already been delineated according to the locus it occupies in the social structure. The delineated intersubjectivity does not necessarily accord with the subject's inner realities; therefore, the social subject is essentially castrated.

In Lacan epistemology, the subject exists within the interplay of three registers, namely, the Imaginary, the Symbolic, and the Real. The roots of the first order have been planted in the Mirror register that occurs roughly between 6-18 months. The subject imagines having an omnipotence power over the self, the mother, and the environment. The subject delves into the second register when it is introduced to language responsible for his social programming. The third register is Lacan's obscure register. It designates the anti-conceptual cause in the unconscious, the real thing in the symbolic, and the objet petit $a$. in the sphere of the Real, language collapses. It is a nonverbal reality where things simply exist without the need for communication. The Real is the truthful to which the subject stumbles but cannot articulate, yet it is revelatory.

Arab World English Journal for Translation \& Literary Studies 
The subject is not conscious in the Symbolic Order. Subjects suffer the residuum of the infantile infatuation with the specular image. When first sees its image in the mirror, the infant responds with a jubilant reflex at seeing the specular gestalt. In contrast to the experienced fragmentation and helplessness, the infant sees itself in the mirror as a whole entity that it controls. Therefore, it becomes infatuated with the specular image that gives an anticipation of an imaginary whole other. The first knowledge of the $I$ occurs in relation to "one's semblable" (Lacan, 2006, p. 79). The specular image marks the emergence of the ego that is a fixation in the psych for an imaginary ideal other that would be forever chased and never obtained. The ego is an inexhaustible primal source of deception and frustration for the subject. Also, it functions as a basis for future identification, responsible for those whom one loves or hates. The ego breeds the emotions of jealousy and aggressiveness.

The Lacanian subject "is divided by the effects of language... that is why he must get out, get himself out, and in the getting- himself-out, ..., to pull himself free" (Lacan, 1998, p. 188). Tournier's text activates Lacan's advice into a psychological praxis wherein the postmodern Robinson escapes the dominion of language in the Symbolic Order, frees himself of the ramifications of the ego in the Imaginary realm, and reaches toward the Real. The inscription of the experience of the unconscious alters the Realism of Defoe's into Tournier's anti-realistic text. The employment of Lacanian signifiers demonstrates the "order of language" rather than the "law of language" (Kristeva, 1998, p. 28). In other words, Tournier's introduces a language that governs the subject and is governed by the subject.

\section{Review of Literature}

Watt (1975) brings forward that Defoe's prose fiction rarely employs figurative language owing to the dominant philosophy of the time and place. It perceives of the figurative language as a medium of deception and ambivalence. It does not refer to the objective world. In the Seventeenth Century, novelists strive to writes the experience of the universal empiricist individual whose identity is unitary, who trusts the inputs of the senses, and is confident of the innocent transparency of language. In the Nineteenth Century, Freud introduces the notion of the unconscious. The modernist's stream of consciousness narrative technique that renders the individual's inner world is a literary the result of Freud's concept. Modernist type of unconscious isolates the subject from the historical and social context. Lacan's psychoanalysis claims that language constructs both the subject's identity and the objective reality. Postmodern literature demonstrates such insight.

Genette (1997) discusses the "hypertextuality" (p. 1) between Defoe's "hypotext" and Tournier's "hypertext" (p. 5). Genett analyzes the relationship under the subcategory of "hypertextual transvaluation" (p.368,) which entails that Tournier replaces Defoe's "axiological system" of the Enlightenment with that of the postmodern (p. 368). By so doing, the text gives primacy to Friday's mythical ways of being over Crusoe's empiricist's counterpart. The thematic transformation entails an alternation in the narrative style, which replaces Defoe's "autodiegetic" authoritative vocalization with a detached fragmented "heterodiegetic narrative" (p. 369). According to Genette, Tournier aims at creating a distance from his hero. Under the current

Arab World English Journal for Translation \& Literary Studies 
investigation, the oscillation between the voices of the first person and the third person signifies the split subject.

Platten (1999) notes that: despite the multiple pre-texts (literary and non-literary) with which Tournier weaves Friday, or the Other Island, Defoe's Robinson Crusoe constitutes the main thread. The Bible, Claude Levi-Strauss's structural analysis of myths, and Rousseau's history of man are other constitutive pre-texts. The weaving of the contemporaneous texts into Friday is Tournier's methodology to rejuvenate Defoe's text. Furthermore, Tournier's logbook -the journal- is among the various intersections with the pre-text. It is the locus wherein the modern preoccupation with language is most evident. Therein, Crusoe ponders that language is his medium to create meaning necessary to order his experience. As time passes on, his referential language malfunctions to adequately articulate the new experience governed by laws of nature. Therefore, he resorts to the "figurative language, which is entirely consonant with Tournier's rewriting project" (p. 66).

\section{Discussion}

Defoe's occupies a kernel position in Western literary and cultural history. It is the first mature novel whose hero has become the Western prototype of the empiricist individual. Tournier's belongs to a long series of "Robinson books" (Genette, 1997, p. 373). Tournier is a bricoleur due to his writing style that mimics the mythical human imagination, which continues to adapt myths to the historical context (Platten, 1999). However, Tournier's recycling tendency has gone too far; there are three versions of Friday, or the Other Island. In addition to the first one, which is the object of the ongoing investigation, the second is Vendredi ou La Vie Savage translated as Friday (1971); the third is an edition tailored for children Vendredi, au La vie Savage in English Friday and Robinson (1972). Tournier's first text restricts to the plotline of Robinson's experience on the deserted island, disregarding the prior and post solitary adventures. Instead, it uses a prologue and an epilogue. In the former, disguised in a prophecy, Robinson's voice gives a synopsis to the familiar plot about his experience on a secluded island. In the latter, owing to the new knowledge acquired from the Lacanian quest, Robinson departs from the familiar story and decides to continue living on the island.

Defoe's realist text presents the mythical hero of the enlightened individual whose rational faculty has been instrumental in developing the capitalist society. He cultivates a virgin land, and colonizes the indigenous races. Reality has passed the empiricist test since Crusoe has replicated a version of the familiar reality of the Enlightenment (henceforth, Crouse refers to Defoe's and Robinson to Tournier's). Tournier's aborts the empiricist experiment by incorporating the irrational experience of the unconscious, which has led to a category of knowledge unreachable by reason. The text represents a dialogical relationship between the viewpoints of the conscious reality and the unconscious fantasies.

Tournier's text begins by establishing an anti-realist identity antithetical to Defoe's. On the one hand, Defoe's starts with a chapter that affirms the authority of the conscious reality of the Symbolic Order, Tournier's opens with a prologue of images, emulating the system of signification of the unconscious. The pictures narrate a prophecy, which is the plot. The images operate as 
signifiers; they signal at something significant in the storyline, yet the meaning is only a matter of speculation. In the first half of the prophecy, the pictures refer to the familiar content of Defoe's. Therefore, the reader derives some meaning. The second half sounds like nonsense because Tournier's text has gone its route; the signifiers fold the reference inward to yet to be read plot. The images of the prologue sketch the anecdote in a few pages. Due to the enigmatic traits of the poetic code, the reader realizes the linguistic trick belatedly as the novel closes. The text gives the reader a taste of the true nature of the sign system. Language is a potent living entity that constructs rather than represents.

Since people are the active agents in tightening the grip of language, Robinson needs to lead a solitary existence. Therein, by going back into his biography, Robison is reborn as a free individual. Firstly, Robinson needs to tackle the signifiers constructing the reality of his unconscious. On the sailing ship, the captain, Van Deyssel predicts Robinson's future using the pictures of the tarot-pack. The first image shows "the demiurge," which is one of the gods of order; "one who does battle with a world in disorder which he sees to master by whatever means come to hand" (Tournier, 1969, p. 7). The description evokes the figure of the mythological Crusoe. The text suspects the viewpoints of Enlightenment, describing it as "narrow and rigid" (p.7). The text seduces the reader to readily conclude that the primary goal of rewriting is to criticize the Enlightened self and the ramifications of Enlightenment's trajectory. The introductory and the closing episodes consist of phantasmagoria; they narrate the anti-real. They serve to distinguish, and then to emancipate Tournier's hypotext from an inferior subservient attachment to Defoe's hypertext.

The second card shows the hermit, indicating a subject living in solitude. The hermit ventures into a cave from which he emerges as a new subject. Robinson's character is experiencing a change. The cave operates as a signifier, which alters it's signified with accordance to the realm wherein Robinson exists. In the Symbolic Order, it signifies the place of the unconscious wherein the true inner self dwells. Lacan's seminars (2006) suggest such signification alluding to Plato's allegory of the cave as the locus to discover the truth. Following a long journey of exploring the unconscious, the cave's meaning metamorphoses to signify the island's womb. Thereafter, Robinson is the son of the island, signaling an investigation of the subject of the Imaginary Order. Therein, Robinson gets red of the infatuation with the specular image and the subsequent malevolent traces. Some of the following pictures are sterile, yielding no meaning because Tournier's text begins to depart from the familiar text. Yet few remaining images that evoke Defoe's suggest signification. The images indicate the arrival of Friday, who is traditionally assumed to be an agent of anarchy; there is an image that suggests a harmonious coupling between Robinson and Friday that suggests a humanist resolution in their relationship.

Chapter one opens with Robinson marooned on the island. He arrives as a cultured subject divorced from and hostile to the unconscious self. His first act is to slaughter a wild goat whimsically. Robinson resists an exploration of the inner self. Therefore, Robinson's $I$ is symbolized as a "rocky mass, at the base of which was the shadowed opening of a cave" ( Tournier, 1969 , p. 17). The rock mass insinuates the mechanisms of resistance that prevent the subject from 
delving into the unconscious. A colossal cedar guards the fortified $I$. The tree belongs to the text's set of signifiers, for the moment, it refers to the ego. Robinson takes a quick look inside the cave and finds "it to be enormous, so deep and vast that for the present, he could not explore it" (p. 17). The ego resists an investigation that would reveal its falsified origins and ideals. Change implies experiencing an annoying turbulence that would shake off the gratifying stillness resulting from accepting the status quo: "the truth demands that we bestir ourselves" (p. 33). The repetitive surfacing of the unconscious experience in Tournier's text bestirs the annoying exploration.

Robinson opens his eyes on the other island as the branches of the enormous cedar are leaning toward his sleeping body, "as though in a gesture of consolation... [that] have given Robinson a foretaste of what the island could do for him" (p.18). The island is going to change Robinson gently. The island operates as a protean signifier altering the signified in a manner that answers to Robinson's needs in the particular stages of his journey. It respectively takes on the meanings of the country of the unconscious, the mother, the wife, and an eye looking forward to unite with the cosmos, restoring a heavenly primordial state of being, which is the Real.

The island bears the traits of the space of the unconscious; it emerges and fades unexpectedly, mimicking the "pulsative function" of the unconscious that designates "the need to disappear that seems to be in some sense inherent in it" (Lacan, 1998, p. 34). It is a benevolent being "the subject is 'at home' in this field of the unconscious" (p.36). It seeks to lead Robinson toward his subjective truth. Robinson discerns another island "hidden beneath his cultivated island" (Tournier, 1969, p.148); it is a "place more living, warmer and fraternal" (79). Robinson names the island Speranza which means hope. To tempt Robinson to summon his unconscious reality, Speranza addresses the pleasure principle in the subject psyche. As such, the text continues to fluctuate between the realities of the conscious and the anti-realities unconscious.

Instead of rushing into labor as dictated by the reality principle, Robinson initially leads a state of lethargy; thereby, his imagination finds a venue. Robinson imagines that the land is "in constant motion... having rubbery surface on which he could walk and leap if he chose" (p. 21). In a state of laziness, timelessness prevails: "he never knew precisely how many days it was-or weeks or months" (p. 21). On the other hand, the reality principle hinders the subject from a total succumbing to the demands of the pleasure principle. The freshly marooned subject is reluctant to surrender to the natural order; therefore, Robinson alternates between the demands of the two principles. The capitalist I do not appreciate Robinson's state of lethargy, considering it as more appropriate to animals. Within the capital system, time is precious and is measured by the criteria of toil and production. Hallucinations are not appreciated. Labor is vital for Robinson to sustain his sanity. Robinson temporarily yields for the reality principle.

Robinson visits the ship to get whatever he can benefit from on the island. He brings "forty kegs of black powder" (p. 23). Robinson begins to build the Escape boat (p. 24); nonetheless, it is too big that he cannot bring into water. Afterward, he sinks further into a more degenerate state of the animal passiveness "He felt that he no longer had the strength to stand on his own feet, he lived on unmentionable foods, gnawing them with his face to the ground" (p. 35). Moreover, Robinson 
dwells in the mire "over which clouds of mosquitoes hovered" where "the indolent sows, motionless as fallen logs lay there half-buried" (p. 34). The mud drugs the conscious mind paving the way for the memories buried in the unconscious to submerge:

$[\mathrm{H}]$ ere in its warm coverlet of slime, his body lost all weight, while the toxic emanations of the stagnant water drugged his mind... Ride of all terrestrial bonds... his thoughts in half-stupor pursued vestiges of memory which emerged like phantoms from the past ( $\mathrm{p}$. $35)$.

The island aims at exhausting the defense mechanisms of the ego; the initial move is to give Robinson the taste of the pleasures of the world of the unconscious wherein the subject's history is inscribed with signifiers. Robinson begins to conjure some of its content. The trauma of the death of his sister is the first of which. Tasting a little bite of the truth of the inner self, Robinson begins to question the dogmas of the Law of the Father. Robinson realizes that: "the mire ,..., had taught him that he had inherited more than he thought from that little draper in York" (p .36). The last words refer to his father.

Tournier invests the unconscious with sublimating effects. In the mire, Robinson begins to hear "music, unreal yet distinct, like a celestial symphony" (p. 36). Robinson's ego abhors the indulgence to the slumber, yet he hauls to repeat the experience. In Lacan's insights, the unconscious resorts to the mechanism of repetition to draw the attention to a cause: "repetition first appears in a form that is not clear, that is not self-evident, in act... The subject drags his thing into a certain path that he cannot get out of" (Lacan, 1998, pp. 50-51). The act of returning to the mire is a compulsive one that signals a traumatic history that needs to be acknowledged. Robinson locates some of the traumatic experiences that have scarfed his psyche, thus indirectly disturbing his being. Robinson reminisces about his parent's unhealthy relationship, his poor upbringing, and about the fire that has turned his house into ashes. In the state of the initial natural denial, Robinson misperceives of Speranza's intention believing that it provides cruel lessons and pushes him to the verge of madness; therefore, work protects his being against such threatening danger. Work diverges the subject from his inner self.

In chapter two, Robinson begins to write his journals. Language is specifically human. Robinson finds few books whose pages have been sea-washed, thereby provide palimpsests upon which Robinson can write. Robinson reflects on the act of writing:

$[\mathrm{H}] \mathrm{e}$ nearly wept with delight when he traced his first words on paper. In thus performing the noble act of writing, it seemed to him that he half retrieved himself from the abyss of animalism into which he had sunk, and made a return to the world of the spirit. Thenceforward he resorted nearly every day to his journal, not to set down the greater or lesser events of the day, to which he attached little importance, but to record his thoughts, his spiritual progress, his recollections of the past and the reflections to which these gave rise (p.41). 
Writing is an act that is esteemed. Yet it is not the type of writing in Defoe's that registers the humdrum of the empirical reality. Tournier's digs deeper, recording moments of meditation and reflection. Tournier's Robinson argues in favor of the French Rationalism (advocated by Rene Descartes), traditionally argues against the English Empiricism (pioneered by John Locke). Because of an attachment to a transcendental Other- God, the French Cartesian individual reaches certainty through meditation. The English ideology renounces God and is strictly sensory in nature.

Descartes's famous motto "I am thinking therefore I am" (as cited in Lacan, 1998, p. 35) announces the birth of the French rational, enlightened individual. Descartes has proposed that the initial doubt, followed by the individual conscious thinking is the correct mode to reach absolute knowledge. Lacan's relation to Desecrate is oblivious. On the one hand, Lacan admires the Cartesian method of doubt that questions tradition; on the other, he denounces the claim of the certainty of the knowledge obtained by the cogito. Lacan acknowledges the importance of thinking to reach the subjective truth. However, the thinking process is not exclusively conscious. The subject who thinks is sure that he forgets as well, a thought whose source comes from the unconscious. Lacan proposes a new motto for reaching the subject's truth, "I am where I am not thinking" (Lacan, 2006, p. 430). As such, the unconscious participates in the process of thinking, and such intervention leads the subject toward the Real. Instead of dwelling in the filthy mire, writing becomes a medium with which the unconscious can be investigated. The mire is no longer needed. Robinson celebrates the new cultured alternative stating that: "[c]hange was possible without decay!" (Tournier, 1969, p. 79).

Robinson begins to doubt the pillars of the Symbolic Order, which turn to be conveniently constructed to answer temporally for the demands of a particular locality. Robinson writes that his mindset about "moral and religious matters" (p. 46) has begun to alter due to the contextual urgencies. Since "the root of... Christianity lies in the radical rejection of Nature and earthy things, a rejection which I have practiced to excess in regard to Speranza, and which has nearly been my downfall," Robinson must conveniently "retreat ... to more ancient vision of human wisdom, and substitute virtues for virtues (p. 46, emphasis is original). Urgent for his survival, Robinson must change his Western ethos.

Robinson interrogates language that "evokes the peopled world" (p. 48). Gradually, Robinson senses "the process of erosion" (p. 58) his linguistic faculty undergoes as his mental perception becomes more concrete and less abstract. Robinson revises the traditional understanding of the words' depth and surface. Traditionally, we privilege depth over surface. Depth denotes the positive notions of essence, goodness, and meaning. Surface suggests the negative opposite. The discussion maintains that concepts are saturated with cultural denotations, unconsciously mold the subject's conceptions and attitudes. The subject is born as a signifier (a surface) whose signified (depth) has been implied by the Other; Robinson needs to restore his original status as a signifier free from any attachment to a signified. The text privileges the surface over depth, the signifier over signified, the signification over meaning. The quest ends when Robinson loses the need for the sign, thereby escapes the dominion of language. It is an impossible journey; only the hysteric subject escapes the jurisdiction of the Father. Accordingly, the denouement is not heavenly;

Arab World English Journal for Translation \& Literary Studies 
Robinson has not reached the Real but has undergone "a total psychotic catastrophe, the dissolution of the subject's entire universe" (Zizek, 2005, p. 370). Such perspective suggests that Tournier's text parodies any attempt to escape the Symbolic Order, thereby it asserts the subject's enslavement to language.

The conscious Robinson inscribes Benjamin Franklin's capitalist motto on the rocks that symbolize the self "Do not waste time, it is the stuff of life" (Tournier, 1969, p. 113). Robinson works to yield fortune because "'[p]overty robs a man of all virtue'" (p. 133). Hence, Robinson manufactures a water clock so that "my time is marked by this regular ticking, positive, unanswerable, measurable and precise" (p .57). On the cultivated island wherein the rational subject lives, the water clock is activated to measure the linear time. When the unconscious experience surfaces, the clock stops ticking. As such, the time of rest becomes the "the stuff of life" (p. 113). Speranza stops the clock so to release Robinson of the "straitjacket" of the scheduled time (p. 69). Robinson misses a day of labor during which Robinson experiences a unity with the natural world. He notes then deciphers the language of a bird that is: "uttering two distinct cries, one of which told unmistakably of happiness while the other sounded a terrifying note of approaching danger" (p. 69). After that, Robinson has integrated with his natural environment.

Robinson has reached the Mirror Stage. Nonetheless, the unity with the environment stems from the imagination; it is the product of the infatuation with the specular image; it marks the moment the ego comes into being. The infant forges the feeling of unity with the environment to dodge the experienced emotions of the fragmented body. Robinson reworks with the ramifications of the Mirror Stage with the purpose of escaping the fixation of the ego while maintaining oneness with nature. Robinson dreams about the infantile experience of the fragmented body:

Last night my right arm, which was hanging down from my couch, went to sleep or 'died.' I took it in my left hand and lifted it up, that lifeless, heavy object of flesh and bone that might have been a part of some other person, attached to me in error (p.73).

Robinson does not recognize his hand as part of his own body. After that, he looks into the mirror; Robinson reverses the infatuation with the gestalt, he responses to the specular image as "'I am disfigured'" (p.75). Robinson unnaturally accepts the truthfulness about his fragmented body. He does not compensate for the ugly experience with an imaginary whole. The infatuation with the specular image is the mainspring of narcissism, jealousy, aggression, and the false ideals of the Symbolic (Lacan, 2006). Robinson has escaped the ego's negative ramifications.

The next step is to return to the womb when his eyes have been closed. To navigate through the darkness of the uterus, Robinson needs to get rid of the dependence on seeing as a source of perception. Hence, Robinson embarks on an investigation about the role of the eyes on the subject's knowledge. Robinson uses the allegory of the candle to assert the partiality of perception:

A candle carried in a darkened room throws its light on particular objects while leaving the rest in darkness. Things emerge for a moment into light and then return to shadow. But 
whether or not the light has caught them, they do not change, either in their nature or in the fact of their existence (p. 80).

The subject sees things as a result of their refection of light from a particular angle; therefore, our knowledge of things is partial. If our knowledge were to be absolute: "We must substitute another: that of objects shining unaided, with a light of their own" (p. 80). Lacan expresses an identical argument when discussing the split between the eye and the gaze "[w]hat we have to circumscribe ... is the pre-existence of a gaze" (Lacan,1998, p. 72). Lacan discusses the technique of anamorphosis in painting where subjects are compelled to recognize the latent gaze in the act of looking. Lacan discusses Hans Holbein's of The Ambassadors, wherein the skull painted at the bottom becomes realized only from a particular angle of vision. As such, we cannot trust our senses or our knowledge of things.

The gaze accompanies the very moment of awakening. The fetus looks with a gaze indicating that it has experienced a change of its ontological being. Thus, the moment of awakening is traumatic. Before emerging as an eye, the fetus exists in a spatial oneness with the cosmos. The opened eye announces the separation from the pre-ontological. The gaze indicates that: "I emerge from some primal separation, from some self-mutilation induced by the very approach of the real" (p. 83). The trauma comes from the initial perception of the split from the Real, where we are one with the universe.

In his retroactive course, to re-enter the womb, Robinson needs to forsake the function of "seeingness" (Lacan, 1998, p. 81). The perception of the blind seems a convenient alternative. The blinds' perception is spatial; they comprehend their environment through touching. Robinson is ready to venture into the cave to be reborn. At the furthest end of the cave, the womb resides in total darkness. Correspondingly, the signification of Speranza transforms into that of a mother. Robinson reflects: "Speranza was no longer a territory to be exploited but a being, unquestionably feminine" (Tournier, 1969, p. 84). The text portrays Robinson's return to the womb which:

[W]as so small that his hips would not pass. Accordingly, he stripped, and after rubbing his body with the remains of the milk, went headfirst into the bottle-neck, and this time slide down... After a very gentle descent that might have lasted for second or for centuries, he landed ... in a sort of narrow crypt... [on the furthest corner] there was a cavity or recess (pp. 78-88).

The cavity has been crafted to fit his body in the fetus position. Robinson, who puts his "knees drawn up to his chin, shins crossed, hands resting on his feet- which enabled him to fit exactly into the recess that he forgot the limitations of his body directly he had adopted it" (p. 88). Thus, Robinson has reached a state of being wherein there is no "bounds of time and space," where the memory of his mother resides (p. 89). Robinson makes a customary return to the womb for some time-nine months - during which Speranza loses energy as the fruitless trees indicate. Yet Robinson continues to go back. Trespassing the incest taboo puts an end to the pregnancy. Robinson needs to escape the entanglement of the Oedipal complex. 
Whereas Defoe's hero is asexual, Tournier's Robison investigates human sexuality as a way toward the Real. Robinson begins to discuss human sexuality. The island lacks a female figure. Since desire operates metonymically, Robinson forges an alternative sexual partner. Firstly, the sexual desire finds a venue in the figure of a broken trunk, laid on the ground in a manner that resembles the figure of women. Soon after, the perverse affair ends, so to be substituted by a union with Speranza, the mother. Robinson fulfills the supposedly primal desire for the mother. Robinson imagines experiencing a reciprocal love relationship with Speranza. Desire continues to govern Robinson's being. At this point, Friday arrives, and is responsible for freeing Robinson of the desire.

In relation to Defoe's, Friday represents the primitive indigenous subject whose life views favor the ways of nature over that of culture. Robinson initially looks down at the Araucanian, dark-skinned Friday, who belongs to "the lowest stratum of humanity" (p.119). Compared to Defoe's, he is much younger yet shows resistance to his master as his comic mood indicates. Friday's accentuated trait lies in the "youthful outbursts, which threw his [Robinson's] order into confusion and undermined his authority" (p.121). Friday is resourceful. He contributes to the order of the island, solving some of Robinson's problems, one of which is "to dispose of his kitchen waste in a fashion as not to attract the notice vultures and rats" (p.123). Friday resorts to the laws of nature to overcome the problem by making a colony of red ants eating the waste. It offers a critique of the European ethnocentricity.

Within Tournier's context, Friday operates as an "intermediary being," "an "arial being, a sylphs," whose function is to lead Robinson to the field of the Real where the gods dwell (Lacan,1998, pp.30-45). Friday elevates Speranza alongside Robinson to oneness with the cosmos. Robinson senses that [t]he earthy reign of Speranza would be succeeded by a solar reign" (Tournier, 1969, p.147). This speculation conjures back a metaphor of Speranza as an eye. Early on, Robinson hallucinates an imagery of "the island with its rocks and trees was itself nothing but the lid and brow of a huge blue and liquid eye contemplating the immensity of the heavens" (p.21). Like Robinson, Speranza seeks to exist in a spatial oneness with the primal substance of which it has been separated. Tournier has emphasized the metaphor earlier on; then, for the average reader, it operates as a signifier empty of meaning. The text needs to build a linguistic texture for the blank signs to be filled with sense. The reader experiences the process "becoming of signification of signs" (Kristeva, 1998, p.28).

Robinson lingers the earthy reign because of his sexual relationship with Speranza. Friday's function is to gear Robinson to experience the asexual jouissance of being in the place of the sexual one. Robinson has been coupling with Speranza in a pink comb. Robinson notes a new plant with white blossoms that grow exclusively in the areas wherein Robinson copulates with the island. They are his offspring. When Friday arrives, Robinson sees new "striped" mandrakes ( Tournier, 1969, p.136). Robinson becomes furious at the betrayal but exclusively blames "the adulterous earth" (p.144). Speranza has seduced the young boy. Friday liberates Robinson of the primordial desire for the mother and her substitutes: "Robinson was becoming ever more conscious of the gap

Arab World English Journal for Translation \& Literary Studies 
between the image of the island projected into his mind by his garbled recollections of human society" (p.146). To enjoy the asexual jouissance of being, Robinson needs to become feminine.

In the Symbolic Order, jouissance is sexual because it is masculine. In Lacan (1999), desire lives on the notion of love, which provides sexual jouissance. Lacan maintains that Woman, with capital W, is not whole in the Symbolic Order because it is the dominion of Men: "There is no such thing as Woman... by nature of words, we cannot speak of a woman" (p.73). Thus, women's experiences have escaped the system of signification; therefore, it belongs to the realm of the Real. Lacan maintains: "[t] here is a jouissance that is hers about which she herself perhaps knows nothing if not that she experiences it- that makes she knows- she knows it when it comes. It does not happen to all of them" (p.74). Some women experience the jouissance of a content being; they simply experience it without articulating it into words. Lacan goes as far as to claim that such asexual jouissance is a mystic experience that involves a unity with the gods.

The solar reign starts when Friday accidentally explodes the cave. Friday smokes a pipe of tobacco at the entrance of the cave; he throws the tube toward the barrel of the gun powder. The massive explosion turns down the mass of rocks. Thereby Robinson's old self has been terminated, and the new self has been reborn. "Now I have been transported to that other Speranza, I am fixed in a moment of innocence" (Tournier, 1969, p.175). He has escaped timelessness to eternity. Robinson accepts the Real sensory experience without the need to understand, to order, or to articulate. The rescue ship arrives on 30 September 1759; Robinson refuses to go back to the mundane world. Friday disappears.

\section{Conclusion}

In the rewriting the postmodern text, Tournier invests the Lacanian psychoanalysis with at least double ends. One is linguistic; the other is thematic. The former speaks of the latter. Tournier's text operates according to Saussure's self-referential linguistic dynamism. Tournier's version does not mimic the objective world; instead, it refers internally to the world of literature. The text operates as a signifier that correspond to a signified because of internal relations to a manifold of texts, one of which is Defoe's; when built with the proper linguistic structure, it unfolds the reference to itself. Besides, by employing the protean signifier in constricting the text, the text demonstrates how language constructs not only fiction but also the subject's identity alongside the objective reality. Lacanian Psychoanalysis is another text utilized for Tournier's signifiers to refer to yield interpretations. The Lacanian approach dismantles the traditional Western ethnocentricity that rests on reason and the certainty of knowledge. By introducing the irrational part of the self, the desiring subject, and distrusting the senses, Tournier's proposes the alternative postmodern humanism. The text accepts the real and the anti-real, the Self and the Other, nature and culture, and the mainstream and the marginal.

\section{About the Authors:}

Waad Al-Zoubi is a Ph.D. candidate for the doctorate of Philosophy/ English Literature at the University of Jordan. My dissertation investigates Postmodern Metafictional Novel. I hold an M.A degree in English Language and Literature from the Middle East University, Jordan,

Arab World English Journal for Translation \& Literary Studies 
AWEJ for Translation \& Literary Studies Volume, 4 Number 2 May 2020

Michel Tournier's Friday, or The Other Island

Al-Zoubi \& Shaheen

Amman. I worked as a lecturer of English language at Issra University, https://orcid.org/00000001-5708-2471

Prof, Mohammad Shaheen is an honorary professor of English Literature at the university of Jordan. Shaheen holds a Ph.D. degree in English literature from Cambridge University. Shaheen is the author and editor of numerous books and articles in English and Arabic. Recently, Shaheen has received the prize of Kuwait Foundation for the Advancement of Sciences in the field of Arts and Literature for 2019, http://orcid.org/0000-0003-0587-1369

\section{References}

Defoe, D. (2013). Robinson Crusoe. London: Harper Press.

Genett, G. (1997). Palimpsests: Literature in the Second Degree, ( Channa Newman \& Claude Doubinsky Trans.). Lincoln and London: University of Nebraska Press.

Kristeva, J. (1998). Toward a Semiology of Paragrams (Ronald-Fancois Lack, Trans.). In Patrich Ffrench, and Patrich Fancois- Lack, (Eds.), The TEl Quel Reader (pp. 25- 49). London And New York: Routledge.

Lacan, J. (1998). The Seminar of Jacques Lacan Book XI: The Four Fundamental Concepts of Psychoanalysis (Jaques- Alain Miller, Ed). (Alan Sheridan, Trans.), New York and London: Norton \& Company.

Lacan, J. (1999). The Seminar of Jacques Lacan Book XX: On Feminine Sexuality, The Limits of Love and Knowledge (Jaques- Alain Miller, Ed). (Fink, Bruce, Trans) (Jaques- Alain Miller, Ed.) . New York and London: Norton and Company.

Lacan, J. (2006). Écrits. ( Brucke Fink et al Trans.). New York \& London: Norton \& Company. Platten, D. (1999). Michel Tournier and the Metaphor of Fiction. Liverpool: Liverpool University Press.

Tournier, M. (1969). Friday, or the Other Island. ( Norman,Denny,Trans.). England: Penguin Books.

Zizek, S. (2005). Interrogating the Real, London \& New York: Continuum.

Watt, I. (1957). The Rise of The Novel: Studies in Defoe, Richardson, and Fielding. Berkeley and Los Angeles: University of California Press

Arab World English Journal for Translation \& Literary Studies 